\title{
ANALISIS NOVEL PERAHU KERTAS KARYA DEWI LESTARI (KAJIAN STRUKTURALISME GENETIK)
}

\author{
Dwi Siti Pratiwi ${ }^{1}$, Sarwit Sarwono ${ }^{2}$, dan Bustanuddin Lubis ${ }^{3}$ \\ ${ }^{1,2,3}$ Program Studi Pendidikan Bahasa dan Sastra Indonesia \\ Jurusan Pendidikan Bahasa dan Seni \\ FKIP Universitas Bengkulu \\ pratiwidwisiti@gmail.com
}

\begin{abstract}
Abstrak
Tujuan penelitian ini mendeskripsikan pandangan dunia pengarang dalam novel Perahu Kertas karya Dewi Lestari. Penelitian ini berbasis penelitian kualitatif dengan pendekatan strukturalisme genetik. Teknik analisis data, yaitu analisis fakta kemanusiaan, analisis subjek kolektif, analisis pandangan dunia pengarang novel Perahu Kertas, membuat kesimpulan. Hasil penelitian ini berupa (1) kondisi sosial budaya masyarakat yang terdapat dalam novel Perahu Kertas yakni hubungan sosial tokoh dengan lingkungan masyarakat; (2) latar kehidupan sosial budaya masyarakat yang terdapat dalam novel Perahu Kertas yakni pandangan mengenai pekerjaan, status sosial, serta perbedaan antara keinginan orang tua dan keinginan seorang anak; (3) pandangan dunia pengarang dalam penelitian ini yakni mengenai sarjana-sarjana muda yang harus menghadapi realita hidup antara mencari kerja demi eksistensi dan mempertahankan mimpi demi idealisme. Kesimpulan penelitian ini merujuk pada pandangan dunia pengarang yang terdapat dalam novel Perahu Kertas melalui analisis fakta kemanusiaan dan subjek kolektif pada kajian strukturalisme genetik.
\end{abstract}

\section{Kata kunci: Novel Perahu Kertas, strukturalisme genetik}

\begin{abstract}
Abstrack
The purpose of this study is to describe the author's world view in Dewi Lestari Perahu Kertas novel. This research is based on qualitative research with genetic structuralism approach. Data analysis techniques, namely the analysis of facts of humanity, collective subject analysis, analysis of the author's novel view of Perahu Kertas, make the conclusion. The results of this study are (1) socio-cultural conditions of society contained in the Perahu Kertas novel that is the social relations of the figure with the community environment; (2) the socio-cultural life of the society contained in the Perahu Kertas novel, namely the views on work, social status, and the difference between the wishes of the parents and the wishes of a child; (3) the author's world view in this research is about young scholars who must face the reality of life between seeking work for the sake of existence and maintaining dreams for idealism. The conclusion of this study refers to the author's world view contained in Perahu Kertas novel by analyzing the facts of humanity and collective subjects on the study of genetic structuralism.
\end{abstract}

Keywords: Novel Perahu Kertas, genetic structuralism 


\section{PENDAHULUAN}

Perahu Kertas adalah novel karya Dewi Lestari yang bernama pena Dee. Novel Perahu Kertas ini sudah lebih dulu dilansir dalam versi digital pada April 2008, dan kini diterbitkan atas kerja sama antara Truedee Books dan Bentang Pustaka. Perahu Kertas merupakan novel keenam Dee. Setelah sukses menarik perhatian para pembaca dengan buku trilogi Supernova-nya, Dee menerbitkan sebuah novel berjudul Perahu Kertas, yang sempat berhenti selama sebelas tahun karena dilupakan. Akhirnya, novel ini berhasil diselesaikan dalam waktu 55 hari berkat kegigihan dan kenekatan seorang Dee.

Novel berisi semangat dalam meraih mimpi-mimpi. Selain itu, novel ini juga penuh akan nilai-nilai positif serta makna kehidupan yang tidak hanya bercerita tentang remaja pada umumnya, tetapi bercerita tentang dinamika kehidupan seperti Kugy yang mempunyai cita-cita menjadi seorang pendongeng dan penulis tetapi karena menjadi seorang pendongeng tidak akan memenuhi kebutuhan akhirnya Kugy memutuskan untuk mencari pekerjaan lain. Sedangkan Keenan ia terpaksa harus menggantikan ayahnya untuk memimpin perusahaan padahal cita-citanya ingin menjadi seorang pelukis yang handal.

Dewi Lestari, yang dikenal dengan nama pena Dee Lestari, lahir pada tanggal 20 Januari 1976 di Kota Bandung, Jawa Barat, dari pasangan Yohan Simangunsong dan Tiurlan Siagian. la adalah anak keempat dari lima bersaudara. Tiga saudara perempuannya juga aktif di bidang seni. Kakak perempuannya, Key Mangunsong, adalah seorang sutradara dan penulis skenario. Kakak perempuan keduanya, Imelda Rosalin adalah seorang pianis dan penyanyi jazz. Adik perempuannya, Arina Ephipania, adalah seorang penyanyi dan merupakan vokalis band Mocca.
Menulis adalah hobi yang dilakoni Dee sejak kecil. Sejak umur 9 tahun, ia sudah berkhayal satu saat nanti pergi ke toko buku dan menemukan buku yang ditulisnya sendiri. Beranjak SMP, Dee mulai mencoba menulis cerpen remaja, mengirimkan ke majalah dan tidak berhasil, begitu juga ketika beberapa kali mengikuti lomba.

Perahu Kertas, Filosofi Kopi, Rico de Coro, adalah beberapa contoh karya yang ia tulis semasa di bangku kuliah dan baru diterbitkan lebih dari sepuluh tahun kemudian. Tahun 1993, Dee tergerak ikut lomba menulis artikel yang diadakan majalah Gadis.

Pada saat menulis cerita Perahu Kertas, Dewi Lestari terinspirasi dari empat hal, yakni Katyusha, Popcorn, Indigo Girls, dan Reality Bites. Pertama, Katyusha adalah penulis tahun '80-an yang pernah terkenal dengan karya-karyanya di majalah remaja. Kedua, Popcorn adalah judul komik Jepang sepanjang dua puluh enam seri yang di tulis oleh Yoko Shoji. Ketiga, Indigo Girls adalah dua penyanyi atau gitaris perempuan asal Amerika, terdiri dari Emily Saliers dan Amy Rey. Keempat, Reality Bites adalah judul film produksi tahun 1994.

Untuk memudahkan penulis dalam menganalisis, maka penelitian ini difokuskan pada pandangan dunia pengarang dalam Novel Perahu Kertas Karya Dewi Lestari. Dengan rumusan masalah pada penelitian ini adalah bagaimana pandangan dunia pengarang dalam Novel Perahu Kertas Karya Dewi Lestari?

Sejalan dengan hal itu, penelitian ini bertujuan untuk mendeskripsikan pandangan dunia dalam Novel Perahu Kertas Karya Dewi Lestari. Berdasarkan penjelasan diatas, penelitian ini menggunakan teori strukturalisme genetik. 
Strukturalisme genetik dikembangkan atas dasar penolakan terhadap analisis strukturalisme murni, analisis terhadap unsur-unsur instrinsik. Strukturalisme genetik ini merupakan gerakan penolakan strukturalisme murni, yang hanya menganalisis unsur-unsur intrinsik saja tanpa mengindahkan hal-hal di luar teks sastra itu sendiri (Ratna, 2007:121).

Faruk (2012:58) menyatakan Goldmann percaya bahwa karya sastra merupakan sebuah struktur. Artinya, ia tidak berdiri sendiri, melainkan banyak hal yang menyokongnya sehingga ia menjadi satu bangunan yang otonom. Akan tetapi, Goldmann tidak secara langsung menghubungkan antara teks sastra dengan struktur sosial yang menghasilkannya, melainkan mengaitkannya terlebih dahulu dengan kelas sosial dominan. Sebab, struktur bukanlah sesuatu yang statis, melainkan produk dari sejarah yang terus berlangsung, proses strukturisasi dan destrukturisasi yang hidup dan dihayati oleh masyarakat asal teks sastra yang bersangkutan. Strukturalisme genetik mencoba mengkaitkan antara teks sastra, penulis, pembaca (dalam rangka komunikasi sastra), dan struktur social.

Konsep dasar yang membangun teori strukturalime genetik, yaitu fakta kemanusiaan, subjek kolektif, pandangan dunia pengarang dan pemahamaan dan penjelasan (Faruk, 2016, hal 56)

Fakta kemanusiaan merupakan suatu struktur yang berarti. Artinya fakta-fakta itu sekaligus mempunyai struktur dan arti tertentu. Oleh karena itu, pemahaman mengenai fakta-fakta kemanusiaan harus mempertimbangkan struktur dan artinya. Fakta itu memiliki struktur karena terikat oleh satu tujuan yang menjadi arti. Dengan kata lain semua unsur yang membangun sastra memiliki arti, dan arti dalam struktur sastra itu didasarkan pada tujuan yang hendak dicapai.
Goldmann (dalam Faruk 2012: 63-64) menspesifikasi subjek kolektif sebagai kelas sosial seperti dalam pengertian Marxis, sebab kelompok itulah yang terbukti dalam sejarah sebagai kelompok yang telah menciptakan suatu pandangan yang lengkap dan menyeluruh mengenai kehidupan dan yang telah memengaruhi perkembangan umat manusia yang terbukti dari perkembangan tata kehidupan masyarakat primitif komunal ke masyarakat feodal, kapitalis dan sosialis. Perubahan yang dilakukan kelas sosial ini adalah perubahan mendasar sampai pada perubahan infrastruktur atau struktur ekonomi masyarakat, tidak hanya perubahan pada tingkat superstruktur.

Pandangan dunia pengarang merupakan suatu ide, gagasan, pikiran, aspirasi dan perasaan yang berkembang sebagai hasil dari situasi sosial dan ekonomi suatu kelompok masyarakat yang ditampilkan melalui problematic hero mengenai hubungan manusia dengan sesamanya dan dengan alam semesta Faruk (2012:65-66).

\section{METODE}

Penelitian ini adalah penelitian kualitatif. Penelitian kualitatif adalah penelitian yang bermaksud untuk memahami fenomena tentang apa yang dialami subjek penelitian misalnya perilaku, persepsi, motivasi, tindakan dan lain-lain, secara holistik dan dengan cara deskripsi dalam bentuk kata-kata dan bahasa, pada suatu konteks khusus yang alamiah dan dengan memanfaatkan berbagai metode alamiah (Moleong, 2007:6). Semi (2012:34) mengemukakan bahwa Penelitian kualitatif lebih sesuai dengan hal-hal yang bersangkut paut dengan masalah kultur dan nilai-nilai, seperti sastra.

Penelitian ini menggunakan pendekatan strukturalisme genetik yang mengacu pada teori strukturalime genetik 
Lucien Goldman yang terdapat dalam (Faruk, 2012:57-64) yang menyebutkan bahwa penelitian strukturalisme genetik mula-mula mencari fakta kemanusiaan (fakta-fakta yang mempunyai struktur yang koheren dan padu serta mempunyai arti tertentu melalui peristiwa), kemudian dilanjutkan dengan subjek kolektif dan pandangan dunia pengarang.

Teknik pengumpulan data menggunakan teknik pustaka dan catat. Teknik pustaka adalah teknik menggunakan sumber-sumber tertulis untuk memperoleh data. Data yang dicatat disertakan pengkodean sumber data untuk mempermudah melakukan pengecekan ulang terhadap data ketika diperlukan dalam rangka analisis data (Subroto, 1992:42).

Adapun Langkah-langkah analisis data penelitian ini sebagai berikut:

1. Menganalisis kondisi sosial budaya masyarakat yang terdapat dalam novel Perahu Kertas.

2. Menganalisis latar kehidupan sosial budaya pengarang dalam menciptakan novel Perahu Kertas.

3. Menganalisis pandangan dunia pengarang novel Perahu Kertas.

4. Membuat kesimpulan.

\section{HASIL DAN PEMBAHASAN}

Berdasarkan hasil analisis Kondisi Sosial Budaya Masyarakat yang Terdapat Dalam Novel Perahu Kerta, Latar Kehidupan Sosial Budaya Masyarakat dalam Novel Perahu Kertas dan pandangan dunia pengarang yang terdapat dalam penelitian, ditemukan hasil sebagai berikut:

\section{Kondisi Sosial Budaya Masyarakat yang Terdapat Dalam Novel Perahu Kertas}

Berdasarkan hasil analisis yang dilakukan pada kondisi sosial budaya masyarakat yang terdapat dalam novel Perahu Kertas yakni tokoh Keenan, seorang anak remaja yang baru lulus SMA. Keenan memiliki hobi melukis dan ia bercita-cita ingin menjadi seorang pelukis dan tinggal di Amsterdam menemani neneknya, tetapi hal tersebut tidak disetujui oleh ayahnya. Ayahnya tidak menginginkan Keenan menjadi seorang pelukis karena menurut ayahnya Keenan lebih baik pulang ke Indonesia dan kuliah di Bandung. Hal tersebut diperkuat dengan adanya fakta bahwa Belanda memiliki banyak pelukis terkenal.

Keenan terpaksa kuliah jurusan Manajemen karena ia tidak pernah diberikan kesempatan oleh ayahnya untuk membuktikan bahwa ia bisa hidup mandiri dengan melukis. Hingga akhirnya Keenan memilih mengikuti kemauan orang tua meskipun itu tidak menjadi dirinya sendiri.

Peristiwa yang dialami Keenan bahwa impiannya menjadi seorang pelukis kandas karena keinginan ayahnya yang menginginkan Keenan untuk kuliah di jurusan manajemen tersebut didukung dengan adanya fakta mengenai pandangan orang tua dan cita-cita seorang anak seperti yang dikemukakan Fazrul (2015) dalam kompasiana berikut ini.

Rasanya tidak bisa dipungkiri bahwa banyak orang tua yang telah memupuk harapan sejak anak masih kecil akan jadi apa mereka setelah lulus pendidikan menengah atas. Ada yang sangat terobsesi agar anaknya menjadi dokter, ada yang ingin jadi Insinyur, jadi sarjana hukum dan lain sebagainya. Semuanya mesti dengan alasan dan latar belakang tersendiri. Bisa saja karena sang orang tua dulu tidak sempat atau gagal menjadi seorang yang mereka harapkan, bisa jadi pula karena yakin bahwa dengan profesi tertentu besar harapan bahwa anak mereka akan sukses secara ekonomi dan berbagai alasan lainnya. Harapan-harapan orang tua ini bisa saja menimbulkan hambatan dan kendala serta perbedaan pendapat dengan anak mereka apalagi jika masing-masing 
pihak tetap dengan alasan masing-masing. Peristiwa tersebut sudah menjadi hal klasik karena selalu terjadi pada tahun ajaran baru akan dimulai.

Setelah menjalankan kegiatan perkuliahan selama enam bulan, Keenan meminta izin kepada ayahnya untuk berlibur ke Ubud. Selama di Ubud Keenan belajar melukis dengan Pak Wayan seorang seniman lukis yang juga sahabat lama ibunya. Setelah kembali dari Ubud, Keenan bertemu dengan Wanda. Wanda merupakan sepupu Noni yang merupakan sahabat Keenan. Wanda yang tertarik dengan lukisan Keenan berniat untuk meletakkan lukisan Keenan di Galeri milik ayahnya. Setelah lukisan Keenan berhasil masuk ke galeri Warsita milik ayahnya Wanda dan Keenan mendapat kabar bahwa lukisannya laku terjual, Keenan akhirnya memutuskan untuk berhenti kuliah.

Keenan yang memilih untuk berhenti kuliah di jurusan manajemen dan meninggalkan keluarganya untuk tetap melanjutkan cita-citanya menjadi seorang pelukis yang terkenal. Hingga akhirnya Keenan memilih untuk tinggal di Ubud bersama Pak Wayan. Selama di Ubud Keenan dengan tekun mendalami hobinya dengan terus melukis. Hingga pada akhirnya lukisan Keenan laku terjual dengan harga tinggi.

Hal tersebut dapat terlihat dengan adanya fakta yang dikemukakan oleh Arnodya (2014) yang menyatakan bahwa di Bali terdapat suatu perkampungan yang hampir seluruh masyarakatnya berprofesi sebagai seniman yakni Ubud. Ubud terletak di Kabupaten Gianyar atau sekitar 1,5 jam perjalanan darat dari Denpasar. Masyarakat Ubud sudah mulai menekuni profesi sebagai seniman sejak tahun 30-an. Bahkan masyarakat disini sudah mulai belajar menjadi seniman seperti melukis ataupun memahat patung semenjak mereka anak-anak.
Fakta kemanusiaan lain yang terdapat dalam novel Perahu Kertas yakni pandangan mengenai pekerjaan menjadi seorang penulis. Hal tersebut seperti yang dikemukakan Siswoyo (2012) dalam artikelnya yang mengemukakan bahwa opini masyarakat terhadap profesi penulis masih belum sepenuhnya diterima. Kemungkinan besar orang akan pesimis terhadap pekerjaan ini. Memangnya bisa hidup dari menulis saja? Dan masih banyak sikap tidak yakin atas profesi ini. Selain itu juga terdapat pandangan orang tua dan cita-cita seorang anak.

\section{Latar Kehidupan Sosial Budaya Masyarakat dalam Novel Perahu Kertas}

Berdasarkan analisis latar kehidupan sosial budaya masyarakat dalam novel Perahu Kertas, Dewi Lestari sebagai penulis menempatkan dirinya sebagai masyarakat Indonesia yang melihat fenomena yang terjadi yakni mengenai pandangan masyarakat di Indonesia mengenai penulis masih sangat minim menurut mereka menjadi seorang penulis bukanlah satusatunya pekerjaan yang dapat menghasilkan dan mencukupi kebutuhan hidup. Banyak penulis-penulis di Indonesia yang memiliki profesi lain seperti menjadi dosen, guru, editor, wartawan, akuntan dan lain-lain.

Selain pandangan mengenai ekonomi ada juga pandangan tentang status sosial yang sering di menjadi fokus masyarakat, bahwa menjadi seorang Pegawai Negeri Sipil (PNS) akan jauh lebih baik dan terpandang dari pada menjadi seorang pedagang, menjadi seorang sarjana akan lebih terpandang, dan beberapa pandangan lain mengenai status sosial. Hal tersebut juga terdapat pada novel Perahu Kertas yang memandang bahwa menjadi seorang pengusaha akan jauh lebih baik dan dari pada menjadi seorang pelukis.

Selain menggambarkan tentang pandangan pekerjaan dan status sosial, 
dalam novel Perahu Kertas karya Dewi Lestari ini juga mengambarkan tentang kepedulian, kasih sayang dan rasa tanggung jawab seorang anak terhadap orang tua dan keluarga. Hal tersebut terlihat ketika Keenan yang sudah memutuskan untuk tinggal dan menetap di Ubud, tiba-tiba Keenan harus pulang ke Jakarta untuk menggantikan ayahnya yang sedang sakit keras.

\section{Pandangan Dunia Pengarang}

Berdasarkan analisis Kondisi Sosial Budaya Masyarakat dan latar kehidupan sosial budaya masyarakat dalam novel Perahu Kertas dapat diketahui bahwa pandangan dunia pengarang dalam novel Perahu Kertas karya Dewi Lestari yaitu bahwa Dewi Lestari sebagai penulis memiliki rasa simpati pada fenomena yang dialami oleh sarjana-sarjana muda yang harus menghadapi realita hidup antara mencari kerja demi eksistensi dan mempertahankan mimpi demi idealisme.

Penulis juga ingin mengungkapkan kepada pembaca bahwa dalam kita semua mempunyai mimpi, punya hobi dan punya kata hati, tapi tidak semua dari kita mempunyai kesempatan untuk menjadikannya sebagai profesi. Kemudian penulis juga ingin mengungkapkan kepada pembaca tentang pandangan-pandangan kelas sosial dan juga status sosial. Selanjutnya pengarang juga ingin mengemukakan kepada pembaca tentang sikap semangat dan disiplin serta memiliki pandangan hidup yang baik dalam usaha untuk meraih cita-cita karena, dalam meraih mimpi akan banyak rintangan yang akan dihadapi termasuk salah satunya adalah harapan orang tua yang tidak sesuai dengan apa yang diinginkan.

\section{PENUTUP}

Kesimpulan

Berdasarkan analisis kondisi sosial budaya masyarakat yang terdapat dalam novel Perahu kertas dan latar kehidupan sosial budaya masyarakat dalam menciptakan novel Perahu Kertas, bahwa pandangan dunia pengarang yang terdapat dalam novel Perahu Kertas yakni Dewi Lestari sebagai penulis memiliki rasa simpati pada fenomena yang dialami oleh sarjana-sarjana muda yang harus menghadapi realita hidup antara mencari kerja demi eksistensi dan mempertahankan mimpi demi idealisme.

Pengarang juga ingin mengungkapkan kepada pembaca bahwa dalam kita semua mempunyai mimpi, punya hobi dan punya kata hati, tapi tidak semua dari kita mempunyai kesempatan untuk menjadikannya sebagai profesi. Kemudian penulis juga ingin mengungkapkan kepada pembaca tentang pandangan-pandangan kelas sosial dan juga status sosial. Selanjutnya penulis juga ingin mengemukakan kepada pembaca tentang sikap semangat dan disiplin serta memiliki pandangan hidup yang baik dalam usaha untuk meraih cita-cita karena, dalam meraih mimpi akan banyak rintangan yang akan dihadapi termasuk salah satunya adalah harapan orang tua yang tidak sesuai dengan apa yang diinginkan.

\section{DAFTAR PUSTAKA}

Arnodya, Rizkiawan. 2014. Ubud, Jantung Kesenian Pulau Dewata, (online://ranselwisata.com/ubudbali.html) diakses tanggal 19 Februari 2014.

Faruk. 2012. Pengantar Sosiologi Sastra dari Strukturalisme Genetik sampai Post-Modernisme. Yogyakarta: Pustaka Pelajar. 2016. Pengantar Sosiologi Sastra dari Strukturalisme Genetik sampai Post-Modernisme. Yogyakarta: Pustaka Pelajar. 
Fazrul, Hesti. 2015. Kuliah: Antara Pilihan Anak dan Maunya Ortu, (online://kompasiana.com/ande_t ercinta/kuliah-antara-pilihananak-dan-maunyaortu_54f6dd8da333113a098b492 2) diperbarui tanggal 18 Juni 2015

Lestari, Dewi. 2012. Perahu Kertas. Yogyakarta: Bentang Pustaka. 2016. Biografi Dee Lestari, (online://deelestari.com/biografi/ ) diperbarui tanggal 14 Februari 2016.

Moleong, Lexy J. 2007. Metodologi Penelitian Kualitatif Edisi Revisi. Bandung: PT Remaja Rosdakarya.
Ratna, Nyoman Kutha. 2007. Teori, Metode, dan Teknik Penelitian Sastra. Yogyakarta: Pustaka Pelajar.

Siswoyo, Agus. 2012. Opini Masyarakat Terhadap Profesi Penulis, (online://ceritaanda.viva.co.id/ne ws/read/288469-opinimasyarakat-terhadap-profesipenulis) diakses tanggal 15 Februari 2012.

Semi, M. Atar. 2012. Metode Penelitian Sastra. Bandung: Angkasa.

Subroto. 1992. Penelitian Kualitatif. Jakarta: Raja Grafindo Persada. 